\title{
A Financial Analysis Exercise: Exxon MobIl vs. Royal Dutch SHELL, US GAAP vs. IFRS
}

Charles 7. Coate, Katherine Holly, and Brian C. McAllister

Charles J. Coate and Brian C. McAllister and professors of accounting at St Bonaventure University. Katherine Holly holds a position with PriceWaterhouseCoopers. The authors wish to thank participants at and the editorial staff of the BRC. We would also like to thank Jenifer Spencer and Dan Michael for their assistance with data preparation. Finally we would like to thank the PwC IFRS grant program for initial financial support.

\begin{abstract}
This exercise is designed to provide non-accounting majors with a learning experience to integrate the international issues of financial statement formats and reporting standards into financial statement analysis. The exercise requires the use of the 2009 10-K of Exxon-Mobile and the 2009 20-F of Royal Dutch Shell including selected footnotes and disclosures. The year 2009 is selected because of the volatility in crude oil prices between 2008 and 2009. The exercise is completed in three distinct assignments stages; each stage permits students to focus on particular elements of the analysis. The first stage focus is differing financial state-
\end{abstract}


ment format and presentation, the second stage focus is cross period and firm analysis, and the third stage focus is US GAAP and IFRS reporting differences. The best learning results are provided if students have a reasonable level of familiarity with financial statement analysis. The exercise has been used is an MBA core accounting course, but is suitable for an undergraduate financial statement analysis course.

Keywords: Exxon, GAAP, IFRS, exercise

DOI: http://dx.doi.org/10.15239/j.brcacadje.2014.04.01.ja04

\section{INTRODUCTION}

The need for international accounting (IFRS) education is widely accepted and has been well documented in the professional and academic literature. Educational support web resources are readily available from a number of organizational and firm sites (see Needles and Powers (2011, p.60) for a complete list). In the professional literature Mintz (2009) notes that over 100 countries have adopted IFRS. Further, with regard to the convergence of US GAAP and IFRS, he states "The availability of IFRS-trained professionals will be a critical success factor” (p. 24). Publications providing insight into the roles of academics can be found in the highest profile publications of the American Accounting Association (see for example, Barth (2008) and Munter and Reckers $(2009,2010)$ ).

Barth (2008) opens her paper by stating that "Globalization of financial reporting is rapidly becoming a reality” (p. 1159) and concludes by stating "...capital markets are demanding a single language of business" (p.1176). Barth (2008) identifies educational and research challenges and opportunities related to global financial reporting. She suggests that educators "need to change how they teach...typically, international accounting has been taught in a separate course.” The implication here is that with the emergence of IFRS around the world, and the convergence of IFRS and US GAAP, an integration strategy is more prac- 
tical. Further, Barth (2008) suggests “... increasing the focus on teaching them the concepts that underlie financial reporting and how to make judgments consistent with those concepts...” (p. 1163).

Munter and Reckers (2009) present the results of the KPMG-AAA 2008 survey on IFRS and accounting curricula; Munter and Reckers (2010) present the results of the KPMG-AAA 2009 survey on IFRS and accounting curricula and where appropriate, 2008 is contrasted with 2009 survey results. Two of their findings are especially relevant to our paper. First is that the two major impediments to the integration of IFRS into the accounting curriculum are making room for the material and the development of materials. Second is that a compare and contrast approach for IFRS and US GAAP is the preferred strategy.

Despite the convergence strategy, US GAAP and IFRS still contain significant differences that are likely to persist into the foreseeable future. Kranacher (2012) suggests that the SEC is "kicking the decision down the road" (p.80). Tysic (2012) lists and discusses issues such as funding, governance, and tax consideration as unresolved hurdles to convergence. It seems reasonable an integrated approach to teaching based on financial (and economic) concepts will remain a valid approach to teaching US GAAP and IFRS.

Integrating IFRS generally translates to integrating into the accounting curricula. The most obvious placement is considered to be intermediate accounting. As noted by Weiss (2011) in her study of 34 programs participating in the $\mathrm{PwC}$ grant program the course that was integrated most often was intermediate accounting. Weiss (2011) added "With most intermediate accounting textbooks including some form of the IFRS convergence literature, it appears the most reasonable and logical course to integrate" (p.62). Weiss (2011) further finds about half the schools also integrated IFRS material into an introductory course and half into an advanced course and a few school integrated IFRS into all courses. 
Future financial statement users will not be limited to accounting majors; accounting faculty must also incorporate IFRS into the education of business students. IFRS coverage for non-accounting majors is topic addressed by Cherubini et al (2011). The authors argue that IFRS should be included in general business curriculum (principles accounting courses). They support this argument from the faculty perspective referencing Munter and Reckers (2009) and from the student perspective relying on their survey (Cherubini et al, 2011 ) where "a majority of respondents thought an introduction to IFRS at the principles level was important to all business majors" (p.13). IFRS coverage should be continued beyond the accounting principles courses to business students as these students become more savvy learners. Presenting such an educational exercise is the purpose of this paper.

\section{THE EXERCISE, ASSIGNMENTS 1, 2, AND 3.}

The exercise requires a financial analysis of the 2009 10-K of ExxonMobile (Exxon) and the 2009 20-F of Royal Dutch Shell (Shell). We choose 2009 because of the relative volatility of crude prices and economic conditions in 2008-2009 driving drops in Sales and Net Income for both companies. Per barrel crude prices began 2008 around $\$ 90$, topped out in July over $\$ 140$ and had dropped to below $\$ 70$ by the end of the year. In 2009 crude prices slowly recovered to just below $\$ 90$ per barrel by the end of the year.

The $10-\mathrm{K}$ and $20-\mathrm{F}$ reports can be obtained from the respective websites of the two companies (or the SEC website). Students are required to analyze the comparative 2008 vs 2009 financial statements of each company and then complete a comparative analysis of Exxon vs. Shell. Students generally have an intuitive understanding of the fundamental business of these companies due to the high profile of the oil and gas industry in the world economy and a student's daily life. 
The oil and gas industry has been suggested as a tool for education by Morehead (2007) and Riordan and Riordan (2009). Morehead (2007) offered a case where comparisons were made between Exxon and BP. Morehead focused on cost flow assumptions and dealt with relatively technical issues; Morehead states "the case is intended for an intermediate accounting course" (p. 558). Riordan and Riordan (2009), even more specialized, suggested using annual reports from the oil and gas industry to study differences in environmental reporting.

This paper's exercise is more general in nature than those in the above articles and is intended to be used in an accounting course for nonaccountants. Rather than focusing on technical accounting issues, the exercise is designed to be more general and flexible. The analysis is easily used by a professor and integrated with other course exercises. Students are required to compare and contrast financial statements with a focus on concepts, economic transactions, selected notes to the financial statements and US GAAP vs. IFRS similarities and differences. The exercise has been used in an MBA core accounting course. Students are required to have completed an accounting foundations course (or undergraduate principles courses) as a prerequisite to the MBA core course; hence the US GAAP vs. IFRS exposure in this exercise is beyond the principles level.

The exercise should be used toward the middle or the end of a financial analysis segment of a course so the students have developed some level of proficiency with financial analysis (ratio, vertical, horizontal, and industry analysis). For example, prior to this exercise the students had completed a number of company financial analysis, including a variety of industries; manufacturing, retail, service and financial. The exercise is designed to be complete over multiple classes; hence, the exercise is divided into the three separate assignments. This allows students to complete and focus on one assignment and understand the material before moving onto the next level of analysis. The objectives by assignment are:

1. Introduce IFRS format and wording differences 
2. Perform F|S Analysis, identify and discuss anomalies (include international issues)

3. Provide potential explanations for anomalies based on footnotes and US GAAP vs. IFRS differences

The materials to be distributed to students are provided in the web appendix. The footnotes and US GAAP vs. IFRS comparisons should not be distributed until Assignment 2 in complete. Teaching notes, solutions, and discussion material are available from the authors.

\section{CONCLUSION}

This paper presents an exercise to analyze Exxon's vs. Shell 2009 financial performance. Footnotes, disclosures, and US GAAP vs. IFRS similarities and differences are used to better understand the financial statements and explain anomalies. As with most US GAAP vs. IFRS classroom materials, shelf life is limited. This is because FASB and ISAB continue work on convergence. Students should be reminded of these efforts with concrete examples. These examples may include the SEC decision in 2007 to eliminate the reconciliation requirement on 20-F filings. Another example is Comprehensive income; students can be direct to the Exxon 2012 From 10-K (p.62) where the Consolidated Statement of comprehensive income may be found. Finally, current convergence projects, as noted by Tysiac (2012), include Revenue recognition. An enduring value of this exercise is its ability to impress upon students the importance of reading the notes and understanding concepts and economic transactions.

\section{REFERENCES}

Barth, M E. (2008). Global financial reporting: Implications for U.S. academics. The Accounting Review 83, 5, 1159-1179. http://dx.doi.org/10 .2308/accr.2008.83.5.1159 
Cherubini, J., Rich, K., Zhu, H., and Michenzi, A. (2011). IFRS in the general business curriculum: Why should we care? The CPA fournal February, 13-15.

Exxon Mobil Corp. 2009 Form 10-K ( <http://www.exxonmobil.com/ Corporate/>.

Exxon Mobil Corp. 2012 Form 10-K ( <http://www.exxonmobil.com/ Corporate/>.

Kranacher, M. (2012) The SEC staff report on IFRS. The CPA fournal August 2012, 80.

Mintz, S. M. (2009). The impact of IFRS on accounting professionals and accounting education Today's CPA. November/December 37(3), 24.

Moreland, K. A. (2007). International financial reporting-inventory costing at Exxon and BP. Issues in Accounting Education 22(4), 549-561. http://dx.doi.org/10.2308/iace.2007.22.4.549

Munter, P., and Reckers, PMJ., (2009) IFRS and collegiate accounting curricula in the United States: 2008 a survey of the current state of education conducted by KPMG and the education committee of the American Accounting Association. Issues in Accounting Education 24(2), 131-139. http://dx.doi.org/10.2308/iace.2009.24.2.131

Munter, P., and Reckers, P. M. J. (2010). Uncertainties and budget shortfalls hamper curriculum progress on IFRS. Issues in Accounting Education, 25(2), 189-198. http://dx.doi.org/10.2308/iace.2010.25.2.189

Needdles, B. E. Jr. and Powers, M. (2011). International Financial Reporting Standards: An Introduction, $2^{\text {nd }}$. Mason $\mathrm{OH}$ : South-Western, Cengage Learning.

Riordan, D. A., and Riordan M. P. (2009). Using annual reports from the oil \& gas industry in the international accounting classroom. Oil, Gas \& Energy Quarterly, September, 58(1), 97.

Royal Dutch/Shell Group. 2009 Form 20-F <http://www.shell.com/>.

Tysiac, K. (2012) Still in flux. fournal of Accountancy September 2012, 28-31.

Weiss, J.M. (2011). Implementing IFRS Curriculum into accounting programs. The CPA Journal April, 62-63. 
64 The BRC Academy Journal of Education Vol. 4, No. 1

\section{WeB APPE ndix}

A web appendix for this paper is available at:

http://dx.doi.org/10.15239/j.brcacadje.2014.04.01.wa04

\section{Citation Information}

Coate, Charles J., Katherine Holly, and Brian C. McAllister. "Financial Analysis Exercise: Exxon Mobil Vs. Royal Dutch Shell, US GAAP Vs. IFRS." The BRC Academy fournal of Business 4, no. 1 (2014): 57-64. http:// dx.doi.org/10.15239/j.brcacadje.2014.04.01.ja04 